\title{
Daniel Defoe and the Whig Tradition in Satire
}

Daniel Defoe was the most prolific satirist of the early eighteenth century. Among his contemporaries, Defoe was known as "the Author of The True-Born Englishman," the sobriquet under which his individual satires were published in addition to his two volumes of collected writings in 1703 and 1705. Over a period of twenty-five years beginning in 1691, Defoe produced at least nineteen verse satires and an equal number of satirical pamphlets. ${ }^{1}$ Until recently, though, Defoe has been mostly discussed by literary scholars as a novelist, and by historians as a topical journalist and government dogsbody. ${ }^{2}$ When considered at all, Defoe's satires (particularly his verse satires) have tended to be dismissed as hack work. ${ }^{3}$ Although Ashley Marshall usefully outlined Defoe's satirical mentalité ten years ago - his focus on anti-Catholicism, liberty of conscience for protestant nonconformists, and the "Reformation of Manners"- there has followed no sustained attempt at analysing Defoe's conception of satire as a modeits history, what he thought satire could accomplish, and how its practitioners should go about attempting this. ${ }^{4}$

My main purpose here is to unpick Defoe's complex and sometimes contradictory thoughts about the history and practice of topical verse satire. My second, related objective is to contextualize Defoe's writings within the forgotten Whig tradition in satire. Despite the surge of interest in Whig literary culture over the past decade or so, scholars such as Abigail Williams have focused almost exclusively on Whig panegyric verse after the Williamite revolution, when the Whigs found themselves in power. ${ }^{5}$ While important and long overdue, the effect of all this recent work on Whig literary 
culture has been to confirm what many literary critics already suspected - that the "characteristic political poetry of the eighteenth century" fits into two neat categories: "Whig panegyric and Tory satire."6 That division has gone virtually unchallenged. Marshall once again touched on the topic in her important overview The Practice of

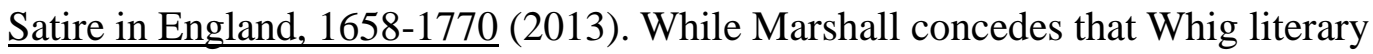
culture is an "identifiable phenomenon," she also argues that it is "broadly ideological and does not equate tidily with satiric practice." Given the current state of scholarship, one would be forgiven for thinking that Whig satire simply did not exist. My aim in this essay is not simply to assert — contra Marshall— that Whig satire is a meaningful category but also to explore the Whig satirical canon from Defoe's perspective. What are the properties of Defovian satire? Do they cohere with or diverge from the Whig tradition? How different are Defoe's satires from those by comparable contemporaries? What can we learn about Defoe's political views from his satires? Only by answering those questions can we begin to understand the importance of satirical verse to Defoe and novelty of some of his poetical strategies.

\section{DEFOE ON "SATYR"}

Working out exactly what Defoe considered satirical is tricky. He uses the label "A Satyr" more nebulously than his contemporaries, although a few preliminary inferences may be drawn. Prose works are never categorized as satire and poems are labelled as satires in no consistent way. For instance, although The True-Born Englishman (1701) and Jure Divino (1706) appear to be exercises in very different genres—witty repartee and ambitious verse essay—both are simply labelled "A Satyr." The Mock Mourners 
(1702) is described as a fusion of disparate genres, "Satyr, By way of Elegy," but neither The Pacificator (1700) nor The Spanish Descent (1702) is defined as satiretheir title pages give only, "A Poem." Did Defoe not consider those poems satirical? That seems unlikely. In a preface added to a later edition of A Hymn to the Pillory (1703), Defoe described it as either "Satyr or Poem, call it which you please." For Defoe, then, "satyr" meant a mode of poetry first and foremost - and for that reason our focus here is on verse and not prose. Only occasionally does Defoe explicitly ruminate on the purpose of poetic satire. In the preface to his earliest known satire, $\underline{\mathrm{ANew}}$ Discovery of an Old Intreague (1691), Defoe stated that "The End of Satyr ought to be, exposing Falshood, in order to Reformation. As all Warrings are Unlawful whose Aim is not Peace; so Satyrs not thus meant, are no more Satyrs but Libells." ${ }^{\text {99 }}$ The distinction was an important and common one: whereas the satirist proceeds with the aim of improving society by exposing vice, the libeller simply attacks with polemical designs. John Dennis elaborated on this in 1720, when he denounced Dryden's Mac Flecknoe (wr. 1678) and Absalom and Achitophel (1681) as "Libels which have pass'd for Satires" not due to a lack of literary merit, but rather because of Dryden's heavy-handed invective: "They are indeed, if you please, beautiful Libels, but they are every where full of Flattery or Slander, and a just Satire admits of neither."10

Contrary to those who wrote libels, Defoe's satirical raison d'être was moral reform. Hence in the preface to A New Discovery he writes: "If no Reformation follows, I must do as Providence does, let you alone to your Own Wills, and as I never drew Pen before, so expect no Second Item" (모, 1:37). In the preface to the so-called "ninth edition" of The True-Born Englishman Defoe repeats that "The End of Satyr is Reformation" and that "the Author, tho he doubts the Work of Conversion is at a general 
Stop, has put his Hand to the Plow" ($, 1: 83)$. The reference is to Luke 9:62, where Christ explains "No one who puts his hand to the plough and looks back is fit for the kingdom of God." Consequently the moral authority of the satirist was crucial. As Defoe explains in the preface to Reformation of Manners (1702), "That no Man is qualified to reprove other Mens Crimes, who allows himself in the Practice of the same, is very readily granted, and is the very Subtance and Foundation of the following Satyr: And on that score, the Author has as good a Title to Animadversion as another, since no Man can charge him with any of the Vices he has reprov'd" (모, 1:155). Defoe's emphasis on moral reform was not unusual in the 1690s and 1700s, when Societies for the Reformation of Manners formed in towns across Britain with the explicit aims of suppressing profanity and immorality. These were evangelical societies and, although Archbishop Tillotson encouraged the groups, largely comprised dissenters and latitudinarians. As Stephen Gregg points out, one of Defoe's classmates from Newington Green preached numerous sermons to those societies. ${ }^{11}$ The likelihood of Defoe's being a member during the 1690 s is extremely high; certainly, he signed up to the Edinburgh society during his visit of $1707 .{ }^{12}$ However, it is also crucial that we remember what historians have taught us - that these were political groups as well as evangelical religious ones. ${ }^{13}$ Lewdness, vulgarity, and impiety were associated with the Stuart courts, godliness with William and the revolution settlement. Defoe's advocacy of satire as a trigger for moral reformation thus entailed a clear Williamite resonance. Poems such as Reformation of Manners and More Reformation (1703), at first glance simple satires on English rudeness, are deeply partisan and, in D. N. DeLuna's words, "urgently topical.",14

The substance of Defoe's verse satires confirms his abstract statements about the 
genre's power to encourage moral reform. Defoe repeatedly uses satire to censure specific categories of behaviour while extolling virtues that ought to be emulated. Most notably in The True-Born Englishman Defoe begins:

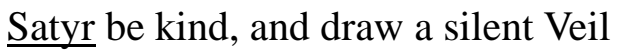

Thy Native England's Vices to conceal:

Or if that Task's impossible to do, At least be just, and show her Virtues too;

Too Great the first, Alas! the last too Few.

Of course, those "few" virtues are all possessed by William III and his counsellors, who are praised at length by Britannia in the penultimate section of the poem. Unfortunately, Defoe writes, the English have vilified and plotted against this virtuous king at every turn. The effect of this contrast is instructive:

The Fact might very well be answer'd thus;

He has so often been betray'd by us;

He must have been a Madman to rely

On English Gentlemen's Fidelity.

For laying other Arguments aside,

This Thought might mortify our English Pride,

That Foreigners have faithfully obey'd him, And none but Englishmen have e're betray'd him. 
$(\underline{S}, 1: 113)$

This disparity between foreign loyalty and English disobedience-nicely balanced in the final couplet-supplies a powerful rationale for the reformation of English political behaviour. Defoe's shift from an abstract "Satyr" to the collective "us" involves his

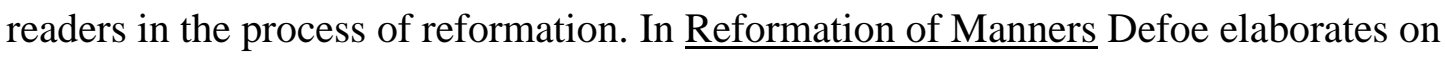
this distinction between right and wrong by differentiating between types of political conduct with a set of clear maxims:

To States and Governments they both extend,

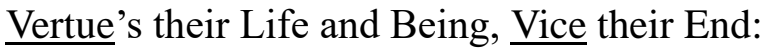

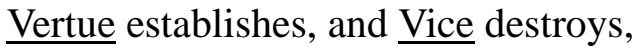

And all the Ends of Government unties:

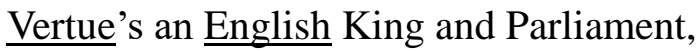

Vice is a Czar of Muscow Government:

Vertue sets bounds to Kings, and limits Crowns,

Vice knows no Law, and all Restraint disowns:

Vertue prescribes all Government by Rules,

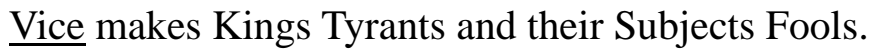

$(\underline{S}, 1: 181)$

This list provides practical guidance for maintaining principles of constitutional rule and avoiding absolutism, encouraging virtue and denouncing vice. As Defoe further explains in his preface to that poem, his satirical target is seldom "private Infirmity" or 
"Personal Vices" but rather public figures "who pretending to suppress Vice; or being vested with Authority for that purpose, yet make themselves the Shame of their Country" (모 1:155). In other words, Defoe's aim is to reform political manners and morals by supplying readers with instructive examples of both vice and virtue by moving from the former to the latter over the course of the poem.

Defoe's most sustained meditation on explicitly political satire comes in $\underline{\text { More }}$ Reformation. Written during the five months Defoe was fugitive after being exposed as the author of The Shortest-Way with the Dissenters (1702), More Reformation articulates the same resentment that found fuller voice in A Hymn to the Pillory. ${ }^{15}$ In it Defoe expresses discontent with topical verse satire as practised by his peers: "Satyr is Nonsense, when it comes from those / Who practise all the Errors they expose" (모, 1:217). The politically versatile Charles Gildon (who later took a pot-shot at Defoe after Robinson Crusoe was published in 1719) is singled out for hypocrisy, as is the Tory satirist William King. Yet Defoe's most pointed remarks are not reserved for his political or literary opponents but rather for the legacy of a dead hero of the Whigs. Addressing a personified "Satyr," Defoe instructs:

No more shalt thou old Marvell's Ghost lament, Who always rally'd Kings and Government:

Thy lines their awful Distance always knew, And thought that Debt to Dignities was Due. Crowns should be counted with the things Divine, On which Burlesque is rudeness and profane; The Royal Banter cannot stand the Test, 
But where we find the Wit, we lose the Jest.

$(\underline{\mathrm{S}}, 1: 228)$

This denunciation of Andrew Marvell as a poetic model is odd; Nicholas von Maltzahn has convincingly demonstrated the extent to which Marvell was canonized as a Whig poet by the start of the eighteenth century. ${ }^{16}$ His diatribes against the Stuart court were an important chapter in the oppositional literary culture from which Whig literary culture emerged. Concluding that "Satyr has no business with the Crown" (ㅁ, $, 1: 228)$ likewise seems a strange position for a confessedly Whig satirist, even one as capricious as Defoe. In his analysis of the passage, Maximillian E. Novak bypasses the issue. For him, Defoe's criticism of Marvell in More Reformation rings false: "he believed that the people (and poets) could rebel against any monarch who threatened to violate the laws of the nation."17 John McVeagh likewise considers it an ironic manifesto against ironic satire. ${ }^{18}$ Certainly, this passage in More Reformation was tactical—an attempt by Defoe to distance his personal brand of satire from the charges of seditious libel he faced for The Shortest-Way. And yet the poem also displays remarkable coherence with Defoe's earlier meditations on satire in the prefaces to and substance of A New Discovery and $\underline{\text { The True-Born Englishman and later remarks in A Hymn to the Pillory and Jure Divino. }}$ Such consistency alone indicates that we ought to take Defoe's comments seriously. If we want to understand how Defoe conceived of Whig political satire, we need to grapple with this reference to Marvell and the continuing legacy of seventeenth-century oppositional satire in the early eighteenth century.

\section{MARVELL AND THE WHIG TRADITION IN SATIRE}


Precisely who or what did Defoe mean by “old Marvell's Ghost'? Determining the attributes of Defoe's "Marvell" is not straightforward. The Marvell canon is almost as disputed as the Defoe canon; there are poems we now attribute to Marvell that were not printed in his lifetime and remained unattributed in Defoe's day. ${ }^{19}$ Nonetheless, any well-informed writer of Defoe's status would have known that Marvell was a patriotic protestant, the MP for Hull, a friend of Milton, and author of anti-court polemics such as An Account of the Growth of Popery and Arbitrary Government (1677) and, of course, satires hostile to the decadence of the Stuart court and the Clarendon ministry. Part of that knowledge would come from widely circulating manuscript copies of verse by Marvell or from poems spuriously attributed to him. ${ }^{20}$ Satires such as The Character of Holland (1653), Clarendon's Housewarming (1667), and The Statue in Stocks-Market (1672-4?), still circulated in manuscript in the early eighteenth century. Although divorced from their immediate political contexts, these pieces retained their polemical valence and remained scandalous some three decades after the events they concern. One anonymous poem from the start of the eighteenth century on " $\mathrm{M}^{\mathrm{r}}$ Andrew Marvells character" admitted that "he might too daringly deride / A Princes Folly or a Prelats Pride," and that "Poetick fury might misguide his Pen." ${ }^{21}$ For this anonymous poet, Marvell spoke truth to power, albeit without tact. But for Marvell's enemies and their successors, these poems were straightforward libels on figures of authority—precisely the sort of "Libells" that Defoe castigated in the preface to $\underline{\text { A New Discovery. }}$

Despite his reputation for libel, Marvell had admirers. Among his earliest disciples were John Freke and John Ayloffe, the first of whom was arrested in 1676 for writing anti-government satires and the second executed in 1685 for his part in the Rye 
House Plot. ${ }^{22}$ In the early days of the Popish Plot, Ayloffe invoked his mentor's spirit to denounce Stuart oppression in a poem called Marvell's Ghost (1679). ${ }^{23}$ John Oldham, though a very different satirist to Marvell, likewise echoed many Marvellian conceits in his Popish Plot satires. In the aftermath of the Exclusion Crisis, John Dryden attacked Marvell's posthumous reputation in Religio Laici (1682), drawing an unfavourable comparison between the dead poet and the author of the radical Marprelate tracts in the 1580 s. ${ }^{24}$ For Dryden, Marvell and his allies were forced to put "Libels and Scurrility to the use of the Good Old Cause" because "(their serious Treatises having been fully answered and refuted) they might compass by railing what they had lost by reasoning; and, when their Cause was sunk in Court and Parliament, they might at least hedge in a stake amongst the Rabble: for to their ignorance all things are Wit which are abusive." ${ }^{25}$ In public, Dryden viewed Marvellian satire as little more than populist character assassination, a strategy of last resort for a waning political movement. Privately, though, he must have thought it a real threat. Why else would he mention it?

Alert to Dryden's antipathy towards Marvell, the statesmen poets Matthew Prior and Charles Montagu, later Earl of Halifax, savaged The Hind and the Panther (1687) in their burlesque The Hind and the Panther Transvers'd (1687), the title of which clearly alluded to Marvell's The Rehearsal Transpros'd (1673). Prior and Montague amended Dryden's verse into a bombastic satire on the Tory Laureate's newfound Catholicism. ${ }^{26}$ On the eve of the Williamite revolution, Charles Sackville, Earl of Dorset, alluded to another Marvell classic, The Last Instructions to a Painter (1667), in his scathing attack on the court of James II, A Faithful Catalogue of Our Most Eminent Ninnies (1688). There is, then, a direct line of influence from Marvell's oppositional satires in the 1660s through to the heyday of Whig literary culture after the accession of William and Mary. 
Satires by Marvell and his followers principally circulated in Defoe's lifetime via printed miscellanies, particularly the Poems on Affairs of State series that ran from 1689 to $1716 .{ }^{27}$ Marvell's name was prominent on the title pages. The first volume of Poems on Affairs of State gave as the author of its contents " $\mathrm{A}-\mathrm{M}-1$ Esq; and other Eminent Wits," as did the second volume. ${ }^{28}$ When the series was revived in 1697 , the new volume contained poems "by the greatest Wits of the Age" including the "Duke of Buckingham, Earl of Rochester, Lord Bu[ckhur] $\underline{\text { st, }}$ Sir John Denham, Andrew

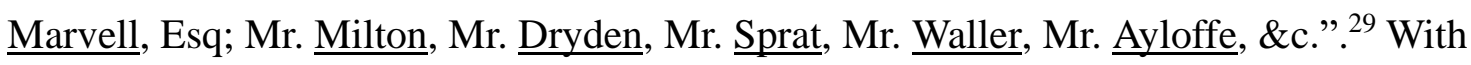
a few exceptions (Dryden, Sprat, Waller) this was a comprehensive list of oppositional poets during the 1660s. Marvell's prominence on the title pages of these miscellanies is reflected in their contents. The 1697 volume began with a set of panegyrics on Cromwell by Dryden, Sprat, and Waller (no doubt intended to humiliate the authors, who switched allegiance after the Restoration) followed by the Advice to a Painter poems attributed to Denham and fifteen poems supposedly by Marvell. These included classics such as the Last Instructions and the epigram Upon Blood's Attempt to Steal the $\underline{\text { Crown, but also a host of spurious attributions to Marvell, including Ayloffe's Britannia }}$ and Rawleigh, the anonymous Nostradamus's Prophecy (possibly also by Ayloffe), and

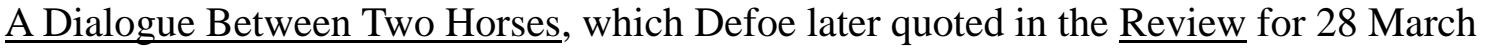
1713, presumably believing it was by Marvell. ${ }^{30}$ Another classic, Clarendon's Housewarming, was labelled in the contents as "Writ by an unknown Hand," despite being set down as Marvell's in various manuscript sources. ${ }^{31}$ Printed attributions stuck. Defoe and his contemporaries included these virulent oppositional satires in the corpus of Marvell's works.

The afterlife of the Second Advice and Third Advice to a Painter exemplify the 
murky authorship associated with Marvellian satire. As a starting point, let us assume Marvell wrote them. ${ }^{32}$ The poems were triggered by Edmund Waller's pictura et poesis panegyric on the Duke of York's naval triumph at Lowestoft in June 1665. Pepys read the Second Advice and Third Advice in manuscript, but had no idea who was responsible for them. ${ }^{33}$ When printed in 1667, they were ascribed to Sir John Denhama joke at Denham's expense. ${ }^{34} \mathrm{Mad}$ at the time — and a true-blue royalist—Denham could not have written the pieces. ${ }^{35}$ That Denham's authorship was fabricated would have been apparent to any well-read Londoner at the time. Pepys did not take the attribution seriously. And yet each printed edition of the poems repeated the patently false attribution. The early editors of Poems on Affairs of State cast some doubt on the authorship of the Second and $\underline{\text { Third Advice, }}$, but they mistakenly attributed the poems to Marvell's friend Milton. ${ }^{36}$ Forty years on, many genuinely believed the Advice to a Painter satires to be by Denham.

Another problematic text is The History of Insipids (1676), a poem that Defoe partially quoted in the Review of 30 May $1710 .{ }^{37}$ John Freke was arrested and interrogated for his authorship of the poem. ${ }^{38}$ Yet the poem was printed under Rochester's name in Poems on Affairs of State. ${ }^{39}$ Benjamin Bragg included it in his scrappy edition of The Miscellaneous Works of the Late Earls of Rochester and Roscommon (1707). In 1709 the pirate printer Henry Hills republished it as Rochester's, together with Ayloffe's Marvell's Ghost and the anonymous Rochester's Farewell

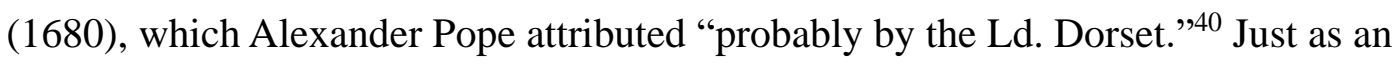
attribution to "Marvell" did not mean the poem was necessarily by the MP for Hull, so "Rochester" was not always a reliable tag: here it meant Freke; elsewhere it encompassed other poets, including, on occasion, Marvell. 
Reflecting on the satirical culture of the Restoration in the Review for 29 March 1711, Defoe listed as the principal practitioners: “Andrew Marvel, Sir John Denham,

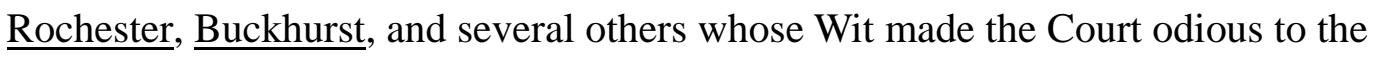
People." 41 This list reveals several things. Firstly, it shows that Defoe read his Denham not in the royalist Poems and Translations of 1668 (reprinted in 1671 and 1684), but rather via the Advice to a Painter satires in Poems on Affairs of State. With the exception of Marvell's Last Instructions, he thought of Denham as the author of the Advice to a Painter series and thus as another opposition satirist. Secondly, Defoe considered Marvell, "Denham," and "Rochester" as a group whose works, as they appeared in miscellanies, were broadly "Marvellian" in the sense defined by Harold Love. ${ }^{42}$ He probably did not realise that his "Denham" was Marvell in disguise, nor "Rochester" a sporadic cover for John Freke. The presence of Buckhurst (by whom he means Dorset) in the group brought this list up to date, from the Anglo-Dutch Wars to the Whig literary culture of the 1690s. Thirdly, and when read in the broader context of the essay, it emerges that Defoe by-and-large judged those authors to be seditious. Defoe's argument here is that reintroducing state censorship of the press would encourage rather than stop anti-government libels: "I appeal to any Man that remembers the Days of King Charles II. when the License Tyranny Reign'd over the Press, whether that Age did not abound in Lampoons and Satyrs, that Wounded, and at last went far in Ruining the Parties they were pointed at, more than ever has been practis'd since the Liberty of the Press. ${ }^{43}$ The only way to prevent a new generation of libellers like Marvell and "Denham" is to force them to publish in the open. A free press makes the satirist accountable for his words. In a later essay addressed to his fellow satirists, Defoe 
urges them to "go about it like Poets" in a manner "suitable to the Quality of the Persons, and the Dignity of Satire." ${ }^{44}$

Defoe perceived a Whig tradition of satire founded in the period between the restoration and the Williamite revolution. That Whig tradition was grounded in the anticourt satires of Marvell and Rochester and the exclusionist libels of Ayloffe and Freke. Satires by those authors continued to circulate through the late seventeenth and early eighteenth century in the Poems on Affairs of State miscellanies. By renouncing this oppositional practice of libel in More Reformation and elsewhere, Defoe announced himself as a new breed of Whig satirist.

\section{DEFOVIAN SATIRE IN CONTEXT}

How unusual was Defoe in renouncing the Whig tradition in satire? A comparison between Defoe's satires and those by his nearest professional rival, John Tutchin, proves instructive. Tutchin's career mirrored Defoe's closely. Pope had good reason to group the two together in The Dunciad (1728): "Earless on high, stood unabash'd De Foe, / And Tutchin flagrant from the scourge, below." ${ }^{45}$ The earliest traces of both can be found in Monmouth's rebellion in 1685 and the government clampdown that followed. Whereas Defoe escaped the Bloody Assizes without charge, Tutchin was sentenced to seven years in prison, a fine of $£ 100$, and an annual whipping at every town in Dorseta fate, in Tutchin's words, "worse than death." 46 Having evaded his punishment (probably by bribery), Tutchin turned, like Defoe, to poetry. He wrote a fawning panegyric on William III in An Heroick Poem on the Late Expedition of His Majesty to

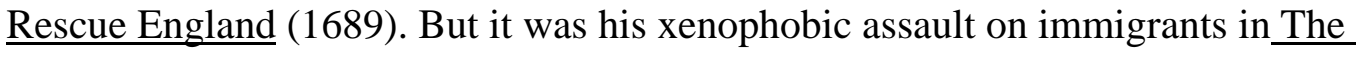


Foreigners which propelled Tutchin to infamy in 1700. This “vile abhor'd pamphlet in very ill verse" occasioned Defoe's The True-Born Englishman as a riposte in addition to poems by other prominent Whigs such as John Dennis. ${ }^{47}$ In 1702 Tutchin established his twice-weekly periodical, The Observator, which acted as a platform for his radical views on current affairs. Later that year Defoe caused scandal by publishing The

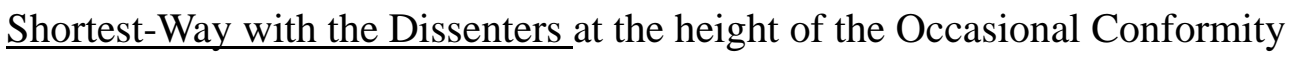
controversy. Tutchin's periodical was the first to report Defoe's authorship of the pamphlet. ${ }^{48}$ Following a manhunt, Defoe was charged with seditious libel and sentenced to stand in the pillory in July $1703 .{ }^{49}$ Within six months Tutchin's outbursts on the Occasional Conformity debate landed him in similar trouble. On 3 January 1704, parliament issued a warrant for "the said John Tutchin, for the said Offence, in Breach of the Privilege of this House. $" 50$ Tutchin refused to stand down, forcing the government to issue a reward of $£ 100$ (double the $£ 50$ prize for information leading to Defoe’s arrest) for apprehending the author, who eventually surrendered himself in May. ${ }^{51}$ Unlike Defoe, Tutchin escaped charges of seditious libel on a technicality. ${ }^{52}$ He returned to journalism and became Defoe's sparring partner in the press until he was murdered in 1707.

Given their shared past, we might reasonably expect points of contact between satires by Defoe and Tutchin. As dissenters, they often have the same targets: papists, Jacobites, Tories. And yet it immediately emerges that they have very different satirical

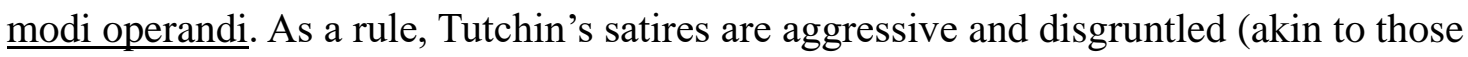
by Ayloffe or Freke), whereas Defoe's are usually defensive. ${ }^{53}$ Consider, for example, their respective responses to the bungled naval operations of $1702 .{ }^{54}$ Here was a perfect chance for Marvellian satire akin to the Advice to a Painter poems, which exposed naval 
incompetence during the Anglo-Dutch wars. In 1702 the naval commanders George Rooke and James Butler, Duke of Ormond, failed in their attempts to capture the Spanish port of Cadiz. But on their return home they chanced upon the Spanish treasure fleet anchored at Vigo, sank the flotilla, captured much of the silver, and thus secured a victory. ${ }^{55}$ Tory panegyrics on the naval duumvirs were fulsome and many. Tutchin seized his chance to ridicule both the navy and the Tory poets with mock-panegyric verse in The Observator, later reprinted in the 1703 edition of Poems on Affairs of State:

Th' affrighted Fishes to the Ocean swim, And say, Great Ormond, we're afraid of him.

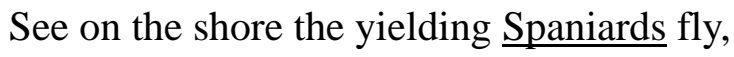
And see on board their Ships the Frenchmen die.

$[\ldots]$

See Neptune yonder the vast Ocean's God, At sight of Ormond hides his Head in Mud.

The Tritons, flouncing thro the Oase, repair

To Rocky Caverns from the fate of War, And all Sea-Monsters bellow from afar. From Vigo's Post to th' Ocean all make way, For here, alas! they dare no longer stay:

By burning Ships the Water's made so hot, Its surface bubbles like a boiling Pot.

Half-roasted Frenchmen, some o'er Gratings broil'd,

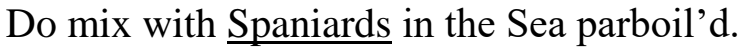


For Anjou's Dinner here's a pretty Dish;

I vow h'has made a Kettle fine of Fish. ${ }^{56}$

Although lacking the wit and sophistication of Marvell, Tutchin was nonetheless attempting something similar to the Advice to a Painter series: transforming the language of naval praise into anti-establishment satire. The repeated directive "See" recalls Marvell's instructions for the painter to "draw" or "shew" the scene. Likewise, the bathetic magnification of small details - here the boiling water, the frightened fishis another hallmark of Marvell's satirical technique. The most Marvellian aspect of Tutchin's satire, though, lies in its purpose. The Advice to a Painter poems had been a dual attack: firstly, on Waller and other royalist poets (including Denham); secondly, on a host of political figures, including the Duke of York, Clarendon, and their advisors. Tutchin likewise aimed at both the Tory poets and Ormond, whose absurd image as the scourge of Poseidon discredits his stature as a naval commander. ${ }^{57}$ In purpose, style, and substance, Tutchin's satire is Marvellian.

Defoe's approach to the victory was different. The mixed qualities of Defoe's satire on the occasion, The Spanish Descent, have been acknowledged by his critics: Furbank and Owens describe the poem as a topical satire on Rooke and the Cadiz failure, Paula R. Backscheider, on the other hand, as "a panegyric on the victory at Vigo." 58 Which is it? Back in 1985 Frank Ellis noted in passing that "only in The

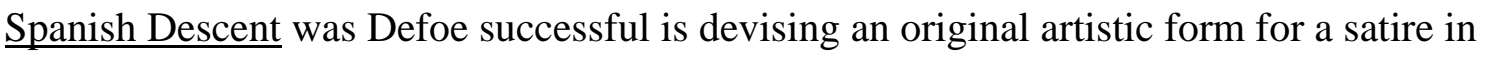
verse," and yet more recently Novak has discerned traces of "Marvell's poetic style" in the poem, by which he presumably means the anti-naval strain of the Advice to a $\underline{\text { Painter series. }}{ }^{59}$ So is the poem Marvellian or "original"? In tone, substance, and poetic 
technique, The Spanish Descent shares almost nothing with the Last Instructions. Blending topical satire with panegyric, Defoe was doing something entirely different from oppositional writers of the seventeenth century and, among contemporaries, Tutchin.

First and foremost, Defoe's poem is an historical rehearsal of events. ${ }^{60}$ His description of the botched attempt to take Cadiz has bite. He deplores the soldiers' conduct, how they "Quit the Andalusian Shores, / Drenched with the Spanish Wine, and

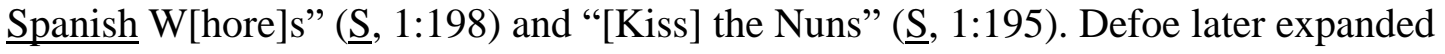
on the theme in A Hymn to the Pillory, where he presented the Spanish as victims of English ignominy: “The ravish'd Nuns, the plunder'd Town, / The English Honour how mispent" (, $, 1: 244)$ — a motif also redolent of The True-Born Englishman. Defoe explicitly reprimands this behaviour. And yet he soon moves away from censure entirely to praise Queen Anne and her counsellors. Shifting the scene to St Paul's, where an elaborate thanksgiving ceremony was held in honour of the victory at Vigo, Defoe describes the queen thus:

See now the Royal Chariot comes amain,

With all the willing Nation in her Train,

With humble Glory, and with solemn Grace,

Queen in her Eyes, and Christian in her Face.

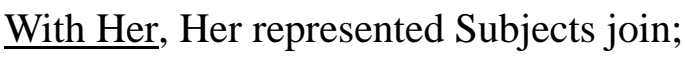

And when She Prays, th' whole nation says Amen.

With Her, in Stalls the illustrious Nobles sat,

The Cherubims and Seraphims of state: 
ANNE like a Comet in the Center shone, And they like Stars that circumfere the Sun.

She Great in them, and they as Great in Her;

Sure Heaven will such Illustrious Praises hear.

This effusive portrait of Anne is filled with images of reciprocity between monarch, people, and parliament; consider, for example, lines such as "She Great in them, and they as Great in Her" or "With Her, Her represented Subjects join," with its curious arrhythmic repetition of the pronoun. Anne's subjects are "represented"-an allusion to England's parliamentary democracy. Consider too Defoe's astral imagery. Royalist poets such as Cowley had made extensive use of astral imagery in their panegyrics on the Stuarts. They often depicted the monarch as a comet or rising star (as did Elizabeth's poets) but never invoked other stars-although Marvell discussed the sun-spots that blemished Charles II, the "Sun of our world," in the Last Instructions. ${ }^{61}$ By contrast, those other stars are central to Defoe's praise: "they like Stars that circumfere the Sun." His implied message is that Anne is a part of the polity, neither above nor separate from it. Her political strength is built on that of parliament and the people, and parliament's, in turn, is founded on the revolution principles of constitutional rule. There is no mockery in Defoe's panegyric. Consequently, this is a very different sort of poetic response to naval incompetence by Tories. Whereas Tutchin embraced the Whig tradition of the Painter poems, Defoe turned his back on that tradition and instead counterbalanced his satire with praise of revolution principles.

The Spanish Descent is no exception. We find similar praise of constitutional 
monarchy in satires such as The Mock Mourners and The Dyet of Poland (1705). Once again, a comparison with Tutchin throws this strategy into relief. In The British Muse (1702), The Mouse Grown a Rat (1702), and various issues of The Observator, Tutchin attacked the Jacobite poets who mourned the recently deceased James II:

England, rejoice! thy slavish Fears are past;

The Tyrant's dead, who was thy worst and last.

Encircl'd he's within the Shades of Night,

Confin'd far distant from the Realms of Light;

No more thy Liberties he shall invade,

Subvert thy Laws, and undermine thy Trade.

Whilst impious Pens usurp illegal Fame,

And Honours give to his detested Name,

My British Muse in justest Notes shall sing

A Bankrupt Monarch, and a Tyrant King. ${ }^{62}$

The Dutch political philosopher Bernard de Mandeville did something similar in The

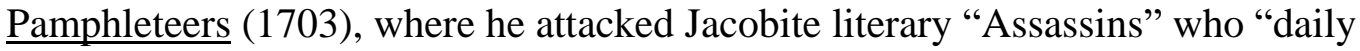
practice Murder" on the "Fame" of William III. ${ }^{63}$ Defoe, by contrast, passes over the Jacobites and instead patiently explains in The Mock Mourners that Anne, like William, will rule according to revolution principles:

In William's Steps sedately she proceeds,

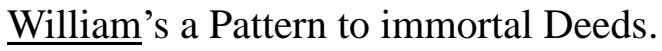


Preserves his Memory with generous Care;

Forgetting him is Disobliging her;

$[\ldots]$

'Tis William's Glorious Scepter which she bears

Like William she for Liberty appears.

She Mounts to Honour by the Steps of Truth, And his Example Imitates in Both.

$(\underline{S}, 1: 152)^{64}$

In The Dyet of Poland, Defoe likewise reminds his readers how William, "With mild and gentle, but with steady Hand, / He rather led than rul'd th' uneasie Land" (모, 1:348). This is not sarcastic. In The Pacificator, too, Defoe opens not with a salvo against Tories, but with praise of "Victorious $\underline{\text { NASSAU" }}(\underline{S}, 1: 65)$. Defoe's political satires consistently incorporate eulogy of the monarch in addition to passages aimed at their detractors.

The satirical effect of this eulogy goes beyond simply providing readers with a contrasting model of virtue which they should seek to emulate. By praising Anne as a constitutional ruler in The Spanish Descent and elsewhere, Defoe is also striking a blow at the Tory writers who praised her as an hereditary monarch ruling by divine right. ${ }^{65}$ On the other hand, by embracing panegyric and rejecting libel Defoe also distances himself from the Whig tradition in satire. By carving out a middle path, Defoe's intention here is seemingly not the reformation of manners but rather the reformation of poetry. As Defoe saw it, the aim of satire was to instruct. Read alongside his critique of absolutist politics, then, Defoe's eulogy of Anne as a morally steadfast constitutional 
monarch alerted readers to the supposed falsehoods inherent to Tory panegyric, and might in turn direct poets on all sides towards a new and more balanced model of praise and blame.

\section{JURE DIVINO AS SATIRE}

What can Defoe's combination of satire and panegyric tell us about his politics? Much ink has been spilled on Defoe's political identity. He was ever the contrarian, always quarrelling with other dissenters and Whigs. ${ }^{66}$ Defoe's political satire is more consistent than his journalism, though still far removed from opinions voiced by the Junto or by rabble-rousers such as Tutchin. Perhaps the most contentious interpretation of Defoe's politics is proposed by Manuel Schonhorn, for whom Defoe was an unreconstructed royalist. ${ }^{67}$ Critics have generally been suspicious of Schonhorn's arguments — and rightly so. Yet it is easy to understand how Defoe's comments about the inviolability of monarchs in literature could be interpreted in this manner. Critical opinions of Defoe's politics have almost always been based on his polemical tracts, his journalism, and occasionally on Robinson Crusoe and other novels. Jure Divino has featured prominently in the discussion too, but has seldom been treated as a "satyr" nor discussed alongside Defoe's other satires. As John Richetti observes, "the satire so prominent in the title tends to be ignored or given second place to the illustration of his notions about constitutional and contractual monarchy." ${ }^{68}$ Even Marshall—whose account of Defoe-as-satirist is our most thorough—does not deal with Jure Divino as a satire in any serious or sustained way. Refusing to accept $\underline{\text { Jure Divino as a satire means }}$ we miss much of the poem's subtlety. In the final section of this essay, I want to take a 
fresh look at Jure Divino, resituate it in the context of Defoe's earlier satires, and refine our understanding of Defoe's satiric output.

Jure Divino was years in the making. Although the poem was among his last when published in July 1706, Backscheider suggests that Defoe started composing it soon after finishing The True-Born Englishman in $1701 .{ }^{69}$ Certainly, we know that Defoe was working on it while a prisoner in Newgate in 1703 after The Shortest-Way debacle. It is easily Defoe's most ambitious work - novels notwithstanding — and is probably the work by which Defoe hoped to be remembered. Satirical aspects of Jure Divino are easy to spot, as is the broader satirical argument concerning the doctrine of the divine right of kings. At first glance this could appear to violate Defoe's rule that monarchy is above satire. No so, he writes: "If any are so weak as to suppose this is a

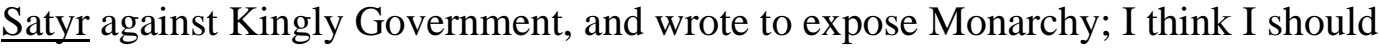
sufficiently answer so foolish a Piece of Raillery, by saying only, they are mistaken" ($\underline{\text {, }}$ 2:38). There is considerable overlap with Defoe's other verse satires. Verbally, there are numerous parallels. Consider, for instance, Defoe's assertions in Book II of Jure Divino that "Title and Right's an empty formal Word" ($, 1: 118)$ and "Rule without Power's an empty senseless Word" ( $\underline{\mathrm{S}}, 1: 119)$ a formulation that recalls an earlier couplet from $\underline{A n}$ Essay on the Late Storm (1704): "Loyalty's a sensless Phrase, / An empty Nothing which our interest sways" ( $\underline{S}, 1: 291)$. Thematically and tonally, too, Defoe repeats himself. When we read Defoe's great verse satire, we must remain aware of those other satires that Defoe composed alongside it.

Yet Jure Divino also contains many complimentary passages. Critics familiar with "Augustan" satire have not known how to deal with these. To be sure, one might think of Absalom and Achitophel (1681) as a blend of satire and panegyric - but that is 
a polemical work, not a philosophical one akin to Jure Divino. As Howard Weinbrot observes: satirists writing in the classical tradition knew that "poems called satires usually included more blame, and epistles more praise, and that their tone, content, and poetic strategy would vary accordingly."70 This judgement does not apply to $\underline{\text { Jure }}$

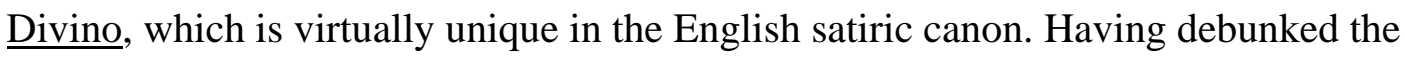
hereditary principle and absolute monarchy, the final two books are given over entirely to eulogy of King William, Queen Anne, and their counsellors. By now this strategy should be familiar. We have already seen how Defoe consistently absorbed eulogy into his poetic arguments in poems such as The Mock Mourners, The Spanish Descent, More Reformation and The Dyet of Poland - how praise became an integral part of his satirical technique. And yet these sections of Jure Divino have largely been misapprehended by critics. John McVeagh, for instance, argues that "it is not so much a development from one mode to another as a juxtaposition. Both satire and panegyric run through the work." ${ }^{\prime 71}$ For McVeagh, Defoe makes these two genres work in conjunction, but they are still essentially disparate.

Once we take a closer look at those late books, though, it becomes clear that Defoe did not differentiate between "satyr" and panegyric, nor alternate between genres. Eulogy was part-and-parcel of his satiric technique. Opening Book XI, Defoe writes: "SATYR, from Fact, to Consequence descend, / Just Princes and just governments defend" ( $\underline{\mathrm{S}}, 2: 316)$. Here satire defends legitimate rule by praise. The appeal to "Satyr" at the outset of Book XII is even more overt:

SATYR lay down thy Arms, some Truce proclaim, And draw a Curtain over Latent Crime; 
Close the vast Scene with Smiles, and let us see,

Thy Zeal for Vertue cloath'd with Majesty.

Defoe could hardly make his position clearer. Jure Divino does not comprise two different genres; the poem's panegyric strains are still voiced by "Satyr," who has a "Zeal for Vertue." Later in Book XII, Defoe even instructs "Satyr" to "forbear, unless thou'lt end thy Days, / Lost in vast Labyrinths of successive Praise" ($, 2: 353)$. Evidently we need to sharpen our critical vocabulary: "Satirical" praise is not the same thing as fawning panegyric. Defoe opened Jure Divino with an extended footnote on the instructive purpose of satire - and praise could likewise prove instructive. As he explains later in the final book: "Remember, Flattering Words no Glory raise, / Are useless here, and Truth's Her only Praise" ($, 2: 359)$. The job of "Satyr" is to show "ANN's true Picture" and "balance well Her Vertue and Her State" (ㅁ, 2:359). This is honesty, not sycophancy. If, as Defoe argued in A New Discovery, "The End of Satyr ought to be, exposing Falshood, in order to Reformation," then describing a paradigm of monarchy seems the most logical way to conclude a cautionary satire on tyranny.

But why choose satire as a vehicle for political theory? One possible answer is practical: Defoe wanted to entice subscribers by capitalizing on his reputation as a satirist, as "the Author of The True-Born Englishman." Perhaps he simply felt comfortable within the formal boundaries of satire, although $\underline{\text { Jure Divino has no real }}$ formal precedent. However, a more convincing answer centres on Defoe's political and confessional agenda. We have seen how important moral reform was for Defoe, and how integral to his satirical designs. Whereas prose polemic and the "verse essay" 
discussed by Backscheider used logical argumentation to persuade readers, satire as Defoe conceived it could reform society and warn against the excesses of oppositional politics. Moreover, by directly addressing the poem to Queen Anne, Defoe hoped to counsel her and her ministers to stay true to the revolution settlement. Defoe realized that the familiar rhetorical technique of laudando praecipere - instructing by praisecould also be deployed in satire. ${ }^{72}$ Hence, as a straightforward satire against divine right theorists such as Charles Leslie and (in a previous age) Robert Filmer, Jure Divino has one set of meanings; but as a Defovian "satyr" of political theory, the poem also projects a distinct vision of British politics founded on Williamite principles of constitutional monarchy, liberty of conscience, and the "rational" body politic. If Anne and her ministers saw fit to govern by these principles, and if, like Defoe, her propagandists saw fit to praise them, so much the better.

Our clearest picture of Defoe's plans for further satires in this vein comes in the closing passages of Jure Divino. Turning his attention to a planned sequel, Defoe explains how panegyric could be used as a mode of satire, and satire simultaneously transformed into a vehicle for royal praise:

SATYR when next our Muse inspir'd with Rage,

Commands in just Defence of Truth t'engage;

By Foils present, and make a new Essay;

And try our Vice, by Vertue to display:

Learn by the soft and milky Way to soar,

A Path that SATYR never trod before;

By just Antithesis illustrate Crime, 
And see how strangely Vice and Vertue Chime:

Let gentler Scenes guild thy aspiring Verse,

And Britain's Pride, in Britain's Queen rehearse;

Let the Reverse of Tyranny be known,

And ANN's inlighten'd Character be shown;

Her Panegyrick stabs a Tyrant's Praise,

As Hell's long Night's described by Heav'n's long Days.

$(\underline{\mathrm{S}}, 2: 358)$

The second volume was to be given over to "soft and milky" praise of limited monarchy. But, as this passage clarifies, such praise still falls within the remit of satire. Just as eulogy of Anne as a constitutional ruler in The Spanish Descent functioned as satire on Tory writers who praised her as an hereditary monarch who ruled by divine right, so "Her Panegyrick stabs a Tyrant's Praise." The porous nature of satire and panegyric is equally demonstrated in the preface, where Defoe writes that "Every Panegyrick upon King William” was also “a Lampoon upon Divine Right.” Although this mode of satire might function via "Antithesis," at no point does Defoe suggest that he is blending disparate genres. $\underline{\text { Jure Divino }}$ and its sequel were conceived as exercises in pure satire. For Defoe, modern Whig satire was a genre that should deal in truth and expose lies - in this case, what he perceived as falsehoods at the heart of Tory philosophy. Defoe was prescient to the novelty of his approach: his is "A Path that SATYR never trod before," perhaps an allusion to Milton's pursuit of "Things unattempted yet in prose or rhyme." ${ }^{, 73}$ As Milton transformed the epic, so Defoe wanted to reform satire — particularly the dated Whig tradition of opposition libel—into a genre 
of royal praise. In an ideal world, he suggested, there would be no vice to expose, only virtue; no tyrants to reform, only godly monarchs.

The purpose of this essay has been to displace the image of "Defoe as successor to Marvell" described by Ellis, Novak, and others. ${ }^{74}$ Defoe-the-satirist was no Whig of the old school. But nor was he the straightforward royalist described by Schonhorn. To get to the heart of Defoe's politics at the start of the eighteenth century, we need a more nuanced understanding of his verse satires. Defoe perceived a Whig tradition in satire. He rejected that tradition due to its anti-monarchical strain and instead carved out a new role for "satyr" as a vehicle for royal panegyric rather than personal lampoon and invective. Justified praise of constitutional monarchy could instruct political reform, which Defoe viewed as the primary moral impetus behind writing satires. This new mode of Whig satire could not be further removed from the traditional libels of Marvell and his imitators on the one hand, or from the "gloom" of the Tory satirists on the other. Defoe's satires are optimistic in their vision of British politics and confirm that his outlook as a writer was ineluctably shaped by 1688 . His acceptance of Williamite monarchy led him to reject the republican strain of earlier Whig satirical models, such as those provided by Marvell and his followers. Defoe was committed to the revolution settlement, to the constitutional rule of monarchs, and to liberty of conscience for protestant dissenters: principles broadly aligned with the "moderate" strain of Whiggery denounced by Tutchin and other unreconstructed commentators. ${ }^{75}$ Jure Divino may be the fullest statement of Defoe's political philosophy, but is also the most complete instance of his satirical project. In Jure Divino, Defoe did not simply blend satire with panegyric; he used praise of constitutional rulers to satirize arguments in favour of passive obedience and, to quote Pope, "the RIGHT DIVINE of Kings to govern 
wrong."76

Although a few contemporary authors such as John Dunton were inspired by Defoe's conception of satire as a moral balance sheet, his new mode of Whig satire did not catch on. ${ }^{77}$ Reasons for this are unclear, although the ascendance of a Whig ministry in 1705 and the ongoing successes of the War of the Spanish Succession probably encouraged more Whig authors to commit themselves to panegyric than to satire. ${ }^{78}$ Defoe never started his planned sequel to Jure Divino and effectively stopped writing verse satires after that poem was published in 1706 . He composed a few satires on the prospect of union with Scotland and returned fleetingly to poetry in 1715 , when he attacked the Jacobites in A Hymn to the Mob. But no more followed. As Defoe admitted to his readers in the Review for 29 July 1708: "My Harps are long since hung on the Willows, my Brains have done crowing." ${ }^{, 79}$ Defoe's move away from verse soon after 1706 was probably a professional decision as much as an artistic one. He was kept busy by The Review and his duties to Harley did not include poetry. After the Hanoverian succession Defoe became increasingly experimental and fantastical in his prose. It was not long before he found in the burgeoning form of the novel a radical new vehicle for political expression.

1 I have accepted the reduced Defoe canon suggested by P. N. Furbank and W. R. Owens in their A Critical Bibliography of Daniel Defoe (London: Pickering and Chatto, 1998). On the state of the Defoe canon, see Furbank and Owens, The Canonisation of Daniel Defoe (New Haven: Yale Univ. Press, 1988), and Defoe DeAttributions: A Critique of J. R. Moore's Checklist (London: Hambledon, 1994); 
Ashley Marshall, "Did Daniel Defoe Write Moll Flanders and Roxana?," Philological Quarterly 89 (2010): 209-43. On the limitations of the Furbank and Owens canon, see Ashley Marshall, "Beyond Furbank and Owens: A New Consideration of the Evidence for the "Defoe" Canon," Studies in Bibliography 59 (2015): 131-90; Nicholas Seager, "Literary Evaluation and Authorship Attribution, or Defoe's Politics at the Hanoverian Succession," Huntington Library Quarterly 80 (2017): 47-69. See too Maximillian E. Novak's unconvincing position in his introduction to Transformations, Ideology, and the Real in Defoe's Robinson Crusoe and Other Narratives: Finding the Thing Itself (Lanham: University of Delaware Press, 2014), 13-14. Most of the attribution problems in Defoe studies occur later in his career than the verse satires considered here. Whereas Defoe rarely published prose under his own name, almost all of his poetic satires were attributed in print.

2 On Defoe's work for the government, see J. A. Downie, Robert Harley and the Press: Propaganda and Public Opinion in the Age of Swift and Defoe (Cambridge: Cambridge Univ. Press, 1979); P. N. Furbank and W. R. Owens, $\underline{\text { A Political }}$ Biography of Daniel Defoe (London: Pickering and Chatto, 2006).

3 D. N. DeLuna, "Yale's Poetasting Defoe,” 1650-1850: Ideas, Aesthetics, and Inquiries in the Early Modern Era 4 (1998): 345-62. The only full-length account of Defoe's poetry is Andreas K. E. Mueller, A Critical Study of Daniel Defoe's Verse:

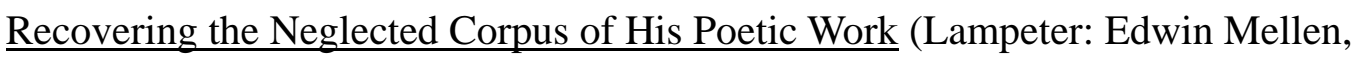
2010).

4 Ashley Marshall, “Daniel Defoe as Satirist," Huntington Library Quarterly 70 (2007): 553-76. Marshall does, however, include both prose and verse satires in her discussion, despite the generic differences between the two. Here I am only 
interested in verse satire.

5 Abigail Williams, Poetry and the Creation of a Whig Literary Culture (Oxford: Oxford Univ. Press, 2005); C. A. Moore, "Whig Panegyric Verse, 1700-1760," PMLA 41 (1926): 362-401. See too the essays collected by David Womersley in "Cultures of Whiggism": New Essays on English Literature and Culture in the Long Eighteenth Century (Newark: University of Delaware Press, 2005). Where recent scholarship has examined Defoe's poetry, it has concentrated on his panegyrics and not his satires: see Andreas K. E. Mueller, "Politics, Politeness, and Panegyrics: Defoe, Addison, and Philips on Blenheim,” Philological Quarterly 94 (2015): 12147; Andrew McKendry, “"No Parallels from Hebrew Times’: Troubled Typologies and the Glorious Revolution in Daniel Defoe's Williamite Poetry," EighteenthCentury Studies 50 (2016): 81-99.

6 Ruth Nevo, Dial of Virtue: A Study of Poems on Affairs of State in the Seventeenth Century (Princeton: Princeton Univ. Press, 1963), 264. Bredvold's influential essay is "The Gloom of the Tory Satirists," in Pope and His Contemporaries: Essays Presented to George Sherburn, ed. James L. Clifford and Louis Landa (Oxford: Clarendon Press, 1949), 1-19.

7 Ashley Marshall, The Practice of Satire in England, 1658-1770 (Baltimore: The Johns Hopkins Univ. Press, 2013), 297.

8 Daniel Defoe, A Second Volume of the Writings of the Author of The True-Born Englishman (London, 1705), sig. A5v .

9 Daniel Defoe, Satire, Fantasy, and Writings on the Supernatural, ed. P. N. Furbank and W. R. Owens and others, 8 vol. (London: Pickering and Chatto, 2003-5), 1:37. All references to this text are hereafter cited parenthetically by volume and page 
number and abbreviated $\underline{S}$.

${ }^{10}$ The Critical Works of John Dennis, ed. Edward Niles Hooker, 2 vol. (Baltimore: The Johns Hopkins Univ. Press, 1943), 2:201. On seditious libel, see Andrew Benjamin Bricker, "Libel and Satire: The Problem with Naming," English Literary History 81 (2014): 889-921; Philip Hamburger, “The Development of the Law of Seditious Libel and the Control of the Press," Stanford Law Review 37 (1985): 661-765; Laurence Hanson, Government and the Press, 1695-1763 (Oxford: Oxford Univ. Press, 1936); Ian Higgins, "Censorship, Libel and Self-Censorship,” in Jonathan

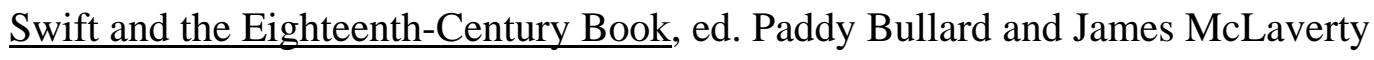
(Cambridge: Cambridge Univ. Press, 2013), 179-98; Thomas Keymer, “Defoe’s Ears: The Dunciad, the Pillory, and Seditious Libel," Eighteenth-Century Novel 6-7 (2009): 159-96; C. R. Kropf, "Libel and Satire in the Eighteenth Century," Eighteenth-Century Studies 8 (1975): 153-68; Andrew McRae, Literature, Satire and the Early Stuart State (Cambridge: Cambridge Univ. Press, 2004); Joseph Hone, "Legal Constraints, Libellous Evasions," in The Oxford Handbook of EighteenthCentury Satire, ed. Paddy Bullard (Oxford: Oxford Univ. Press, forthcoming).

11 Stephen H. Gregg, Defoe's Writings and Manliness: Contrary Men (Farnham: Ashgate, 2009), 98-9.

12 Paula Backscheider, Daniel Defoe: His Life (Baltimore: The Johns Hopkins Univ. Press, 1989), 85-6 and 235-40; Charles Eaton Burch, "Defoe and the Edinburgh Society for the Reformation of Manners," The Review of English Studies 16 (1940), 306-12.

13 Tony Claydon, William III and the Godly Revolution (Cambridge: Cambridge Univ. Press, 1996); T. C. Curtis and W. A. Speck, “The Societies for the Reformation of 
Manners: A Case Study in the Theory and Practice of Moral Reform," Literature and History 3 (1976): 45-64; David Hayton, "Moral Reform and Country Politics in the Late Seventeenth-Century House of Commons," Past and Present 128 (1990): 48-91; Craig Rose, "Providence, Protestant Union and Godly Reformation in the 1690s," Transactions of the Royal Historical Society 3 (1993): 151-70; Tina Isaacs, "The Anglican Hierarchy and the Reformation of Manners, 1688-1738," The Journal of Ecclesiastical History 33 (1982): 391-411; Shelley Burt, "The Societies for the Reformation of Manners: Between John Locke and the Devil in Augustan England," in The Margins of Orthodoxy: Heterodox Writing and Cultural Response, 1660-1750, ed. Roger D. Lund (Cambridge: Cambridge Univ. Press, 1995), 149-69; Jennine Hurl-Eamon, "Policing Male Heterosexuality: The Reformation of Manners Societies' Campaign Against the Brothels in Westminster, 1690-1720," Journal of Social History 37 (2004): 1017-35.

14 DeLuna, "Yale’s Poetasting Defoe,” 352. DeLuna wrongly attacks Frank Ellis’s editorial work in Poems on Affairs of State for being "less concerned to remark the urgent topicality of Defoe's poetry than he is to make Defoe over into an ethical activist” (350). In truth, Ellis frequently remarks at length on Defoe's topicality. Also, Ellis is right to stress Defoe's conception of the satirist as a moral crusader.

15 See Paula R. Backscheider, Daniel Defoe: Ambition and Innovation (Lexington: Univ. Press of Kentucky, 1986), 25.

16 Nicholas von Maltzahn, “Andrew Marvell and the Prehistory of Whiggism," in "Cultures of Whiggism", ed. Womersley, 31-61; von Maltzahn, "Marvell's Ghost," in Marvell and Liberty, ed. Warren L. Chernick and Martin Dzelzanis (Basingstoke: Palgrave Macmillan, 1999), 50-74; Blair Worden, Roundhead Reputations: The 
English Civil Wars and the Passions of Posterity (London: Penguin, 2005), 185-7;

Williams, Whig Literary Culture, 60, 89-90.

17 Maximillian E. Novak, Daniel Defoe: Master of Fictions (Oxford: Oxford Univ. Press, 2001), 202.

18 John McVeagh, "Defoe: Satirist and Moralist," in The Cambridge Companion to Daniel Defoe, ed. John Richetti (Cambridge: Cambridge Univ. Press, 2008), 206.

19 Our only authentic source for most of Marvell's poetry, his Miscellaneous Poems, was printed posthumously in 1681; even then the three major poems on Cromwell were cancelled after the printer apparently lost nerve: see Niall Allsopp, “A Surreptitious State of Marvell's Miscellaneous Poems (1681)?,” Notes \& Queries 62 (2015): 268-70.

${ }^{20}$ On the circulation of Defoe's poems in manuscript, see Frank H. Ellis, "Notes for an Edition of Defoe's Verse," The Review of English Studies 32 (1981): 398-400 and "Defoe's "Resignacon" and the Limitations of "Mathematical Plainness," The Review of English Studies 36 (1985): 338-54; John Knapp, “An Early Holograph Poem by Defoe and His Hymn to Peace," Notes \& Queries 53 (2006): 193-4.

${ }^{21}$ L. A. Davies, “An Unpublished Poem About Andrew Marvell,” The Yearbook of English Studies 1 (1971): 101.

${ }^{22}$ See George de Forest Lord, "Satire and Sedition: The Life and Work of John Ayloffe," Huntington Library Quarterly 29 (1966): 255-73; Marshall, The Practice of Satire in England, 88-9.

${ }^{23}$ Poems on Affairs of State: Augustan Satirical Verse, 1660-1714, ed. George de Forest Lord and others, 7 vol. (New Haven: Yale University Press, 1963-75), 1:285-6. Hereafter POAS. 
${ }^{24}$ On which, see The Martin Marprelate Tracts: A Modernized and Annotated Edition, ed. Joseph L. Black (Cambridge: Cambridge Univ. Press, 2008); Cyndia Susan Clegg, Press Censorship in Elizabethan England (Cambridge: Cambridge Univ. Press, 1997), 170-97; Peter Lake and Michael Questier, The Antichrist's Lewd Hat: Protestants, Papists and Players in Post-Reformation England (New Haven: Yale Univ. Press, 2002), 505-68; Joad Raymond, Pamphlets and Pamphleteering in Early Modern Britain (Cambridge: Cambridge Univ. Press, 2003), 27-52; Jesse Lander, Inventing Polemic: Religion, Print, and Literary Culture in Early Modern England (Cambridge: Cambridge Univ. Press, 2006), 80-109.

${ }^{25}$ The Works of John Dryden, ed. H. T. Swedenberg Jr. and others, 20 vol. (Berkeley: University of California Press, 1956-2000), 2:106.

26 Williams, Whig Literary Culture, 89-90. On the broader influence of The Rehearsal Transpros'd on eighteenth-century satire see Matthew C. Augustine, “"A Mastery in Fooling': Marvell, the Mock-Book, and the Surprising Life of "Mr. Bayes', Studies in Philology 112 (2015): 353-78.

27 On the Poems on Affairs of State series, see John McTague, "Censorship, Reissues, and the Popularity of Political Miscellanies," Eighteenth-Century Life 41 (2017): 96115; Abigail Williams, “The Diverting Muse: Miscellanies and Miscellany Culture in Queen Anne's Reign,” in Queen Anne and the Arts, ed. Cedric D. Reverand II (Lewisburg: Bucknell Univ. Press, 2015), 119-34; Steven N. Zwicker, “Poems on Affairs of State (London, 1689-1716 and New Haven, 1963-1975)," 1650-1850: Ideas, Aesthetics, and Inquiries in the Early Modern Era 4 (1998): 345-62.

${ }^{28}$ A Collection of Poems on Affairs of State (London, 1689), sig. A1 ${ }^{\mathrm{r}}$; The Second Part of the Collection of Poems on Affairs of State (London, 1689), sig. A1 . 
29 This formulation was repeated and adapted in later volumes. Marvell's name was also used in newspaper advertisements for the series: see, for example, Post Boy, 342 (15 July 1697); Protestant Mercury, 174 (2 July 1697) and 175 (7 July 1697).

30 For Nigel Smith's list of spurious Marvell attributions, see The Poems of Andrew Marvell, ed. Smith (Harlow: Longman, 2007), 462.

31 Poems on Affairs of State: From the Time of Oliver Cromwell, to the Abdication of K. James the Second (London, 1697), sig. A4 ${ }^{\mathrm{v}}$.

32 On the authorship of the Second Advice and Third Advice, see George de Forest Lord, “Two New Poems by Marvell?,” Bulletin of the New York Public Library 62 (1958): 551-70; Annabel Patterson, “The Second and Third Advices-to-the-Painter," Papers of the Bibliographical Society of America 71 (1977): 473-86; Patterson, “Lady State's First Two Sittings: Marvell's Satiric Canon,” Studies in English Literature, 1500-1900 40 (2000): 395-411; John Burrows, “Andrew Marvell and Painter Satires: A Computational Approach to Their Authorship," Modern Language Review 100 (2005): 281-97.

33 The Diary of Samuel Pepys, ed. Robert Latham and William Matthews, 11 vol. (London, 1970-83), 7:407 and 8:21; see Kate Loveman, Samuel Pepys and His Books: Reading, Newsgathering, and Sociability, 1660-1703 (Oxford: Oxford Univ. Press, 2015), 188.

34 On the printing and Marvell's potential involvement, see Martin Dzelzainis, “Andrew Marvell and the Restoration Literary Underground: Printing the Painter Poems," The Seventeenth-Century 22 (2007): 395-410; Dzelzainis, “L'Estrange, Marvell and the Directions to a Painter: The Evidence of Bodleian Library, MS Gough London 14," in Roger L'Estrange and the Making of Restoration Culture, ed. 
Anne Dunan-Page and Beth Lynch (Aldershot: Ashgate, 2008), 53-66.

35 See Theo H. Banks, Jr., “Denham's Supposed Authorship of Directions to a Painter, 1667," Modern Language Notes 41 (1926): 502-5.

36 Poems on Affairs of State (1697), sig. A4 $4^{\mathrm{r}}$. This recurred in the contents pages of future editions of the miscellany.

37 Defoe's Review, ed. John McVeagh, 9 vol. (London: Pickering and Chatto, 2003-11), 7:139. McVeagh mistakenly gives the poem as Marvell's.

38 See Frank H. Ellis, “John Freke and The History of Insipids," Philological Quarterly 44 (1965): 472-83; Vivian de S. Pinto, “The History of Insipids: Rochester, Freke, and Marvell," The Modern Language Review 65 (1970): 11-5; Hammond,

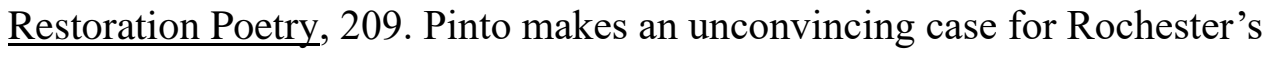
authorship.

39 Poems on Affairs of State (1697), 149. The poem is also given as Rochester's in Bodleian MS Douce 357.

40 [John Freke], History of Insipids, a Lampoon, By the Lord Roch $-r$, with His Farewell. 1680. Together with Marvil's Ghost, By Mr. Ayloff (London, 1709). Pope makes the attribution to Dorset in his copy of A New Collection of Poems Relating to

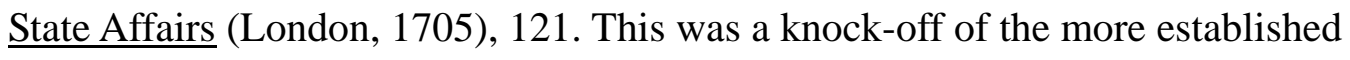
miscellany series, Poems on Affairs of State. Pope's copy is now in the British Library, C.28.e.15. On Pope's attributions in this volume, see Benjamin Boyce, “An Annotated Volume From Pope's Library," Notes \& Queries 203 (1958): 55-7; W. J. Cameron, “Pope's Annotations on “State-Affairs” Poems,” Notes \& Queries 203 (1958): 291-4.

41 Defoe's Review, 8:20. 
${ }^{42}$ Love, Clandestine Satire, 105.

43 Defoe's Review, 8:20.

44 Ibid., 9:304.

45 The Poems of Alexander Pope, ed. Valerie Rumbold and others, 5 vol. (Harlow: Longman, 1999-), 3:231. For a visual comparison, see Joseph Hone, “A New Portrait of Defoe in the Pillory," Notes \& Queries 63 (2016): 70-1.

46 J. G. Muddiman, The Bloody Assizes (London, 1929), 139. See also William Pittis, The True-Born Englishman: A Satyr Answer'd Paragraph by Paragraph (London, 1701), 49; The Examination, Tryal, and Condemnation of Rebellion $\mathrm{Ob}$ [servato] $\underline{\mathrm{r}}$ (London, 1703), 10. We only have Tutchin's word for this story.

47 Daniel Defoe, An Appeal to Honour and Justice (London, 1715), 6.

48 The Observator, 73 (2 January 1703).

49 See Paula R. Backscheider, “No Defense: Defoe in 1703,” PMLA 103 (1988): 27484.

50 Journal of the House of Commons, 85 vol. (London, 1800-30), 14:270.

51 By the Queen: A Proclamation for Apprehending John Tutchin, John How, and Benjamin Bragg (London, 1703).

52 For a comprehensive account of the trial, see Lee Sonsteng Horsley, "The Trial of John Tutchin, Author of The Observator," The Yearbook of English Studies 3 (1973): $124-40$.

53 Marshall, Practice of Satire, 127-30.

${ }^{54}$ For further analysis of literary responses to those naval operations, see Joseph Hone, Literature and Party Politics at the Accession of Queen Anne (Oxford: Oxford Univ. Press, 2017), 110-21. 
55 See Henry Kamen, “The Destruction of the Spanish Silver Fleet at Vigo in 1702," Bulletin of the Institute of Historical Research 39 (1966): 165-73.

56 Poems on Affairs of State: From the Reign of K. James the First to This Present Year 1703 (London, 1703), 415-6. Ellis misses the attribution to Tutchin and mistakenly labels the poem a "feeble panegyric" in POAS, 6:472.

57 Ormond had Jacobite credentials: see Jane Ohlmeyer and Steven Zwicker, "John Dryden, the House of Ormond, and the Politics of Anglo-Irish Patronage," The Historical Journal 49 (2006): 677-706.

58 Paula R. Backscheider, “The Verse Essay, John Locke, and Defoe’s Jure Divino,, English Literary History 55 (1988): 103; Furbank and Owens, Political Biography, 39.

59 Ellis, "Defoe's 'Resignaĉon'," 349; Maximillian E. Novak, "Daniel Defoe and Applebee's Original Weekly Journal: An Attempt at Re-Attribution,” EighteenthCentury Studies 45 (2012): 600.

60 See Noelle Gallagher, “Partial to Some One Side': The Advice-to-a-Painter Poem as Historical Writing,” English Literary History 78 (2011): 79-101. The following discussion of The Spanish Descent draws on Hone, Literature and Party Politics, $124-8$.

61 Marvell, $\underline{\text { Poems, }} 395$

62 [John Tutchin], The British Muse: or, Tyranny Expos'd. A Satyr (London, 1701), 3.

${ }^{63}$ Bernard de Mandeville, The Pamphleteers: A Satyr (London, 1703), 3.

${ }^{64}$ Such language was typical of Defoe's praise of Anne, on which see Nicholas Seager, “'She Will Not Be That Tyrant They Desire': Daniel Defoe and Queen Anne," in Queen Anne and the Arts, ed. Reverand, 41-55. 
65 On those Tories, see Joseph Hone, "Politicising Praise: Panegyric and the Accession of Queen Anne," Journal for Eighteenth-Century Studies 37 (2014), 147-57.

${ }^{66}$ On Defoe's contrary politics, see Furbank and Owens, Political Biography; Yannick Deschamps, "Daniel Defoe's Contribution to the Dispute Over Occasional Conformity: An Insight into Dissent and "Moderation" in the Early Eighteenth Century,” Eighteenth-Century Studies 46 (2013): 349-61; K. R. P. Clark, "Defoe, Dissent, and Early Whig Ideology,” The Historical Journal 52 (2009): 595-614; Clark, Daniel Defoe: The Whole Frame of Nature, Time and Providence (Basingstoke: Palgrave Macmillan, 2007); David Womersley, "Confessional Politics in Defoe's Journal of the Plague Year," in "Cultures of Whiggism”, ed. Womersley, 237-56.

${ }^{67}$ Manuel Schonhorn, Defoe's Politics: Parliament, Power, Kingship and Robinson

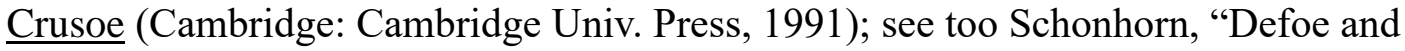
the Limits of Jacobite Rhetoric,” English Literary History 64 (1997): 871-86.

68 John Richetti, The Life of Daniel Defoe: A Critical Biography (Oxford: Blackwell, 2005), 105.

69 Backscheider, Defoe, 161.

70 Weinbrot, The Formal Strain, 164.

71 McVeagh, "Satirist and Moralist," 207.

72 On this technique in eighteenth-century panegyric, see Hone, "Politicising Praise," 149.

73 John Milton, Paradise Lost, ed. Alastair Fowler (Harlow: Longman, 1996), 43.

${ }^{74} \underline{\text { POAS, }}$ 6:xxiv.

75 See Clark, "Defoe, Dissent, and Early Whig Ideology" and McKendry, "No Parallels 
from Hebrew Times."

76 Alexander Pope, The Dunciad in Four Books, ed. Valerie Rumbold (Harlow: Longman, 2009), 298.

77 See, for instance, John Dunton, Dunton's Whipping-Post: or, A Satyr upon Every Body (London, 1706), 14.

78 See Robert D. Horn, Marlborough: A Survey: Panegyrics, Satires, Biographical Writings, 1688-1788 (New York: Garland, 1975).

79 Defoe's Review, 5:264. 